\title{
ANALISIS KUANTITAS TIGA VARIETAS RUMPUT LAUT Kappaphycus alvarezii YANG DIBUDIDAYA DENGAN METODE LONG LINE
}

\section{ANALYSIS QUANTITY OF THREE SEAWEED VARIETIES Kappaphycus alvarezii CULTIVATED BY LONG LINE METHOD}

\author{
Arfan Afandi ${ }^{*}$, Arif Syam ${ }^{2)}$ \\ ${ }^{1}$ Program Studi Budidaya Perairan, Fakultas Perikanan dan Ilmu Kelautan, Universitas Dayanu Ikhsanuddin, \\ Baubau, Indonesia \\ ${ }^{2}$ Program Studi Teknik Informatika, Fakultas Teknik, Universitas Dayanu Ikhsanuddin, Baubau, Indonesia \\ *Korespondensi: arfanafandi05@gmail.com
}

\begin{abstract}
ABSTRAK
Penelitian ini bertujuan untuk menganalisis kuantitas terbaik yang dihasilkan dari varietas coklat, merah dan hijau rumput laut $K$. alvarezii yang dibudidaya dengan metode long line. Penelitian ini dilaksanakan mulai bulan Mei sampai Juni 2014 di Perairan Pulau Panjang, Desa Kamelanta, Kecamatan Kapontori, Kabupaten Buton, Provinsi Sulawesi Tenggara. Rancangan percobaan yang digunakan pada penelitian ini adalah rancangan acak kelompok (RAK) dengan tiga perlakuan dan setiap perlakuan diulang tiga kali sebagai kelompok berdasarkan jarak penanaman yakni darat (jarak tanam 15 $\mathrm{m}$ dari darat), tengah (jarak tanam $30 \mathrm{~m}$ dari darat) dan dalam (jarak tanam $45 \mathrm{~m}$ dari darat). Dengan demikian unit percobaan yang dilibatkan sebanyak tiga unit pada setiap blok sehingga secara keseluruhan dibutuhkan 9 unit percobaan. Perlakuan yang dicobakan pada penelitian ini adalah rumput laut $K$. alvarezii varietas coklat (C), merah (M) dan hijau (H). Parameter yang diukur yaitu kualitas air, klorofil-a, fikoeritrin, laju pertumbuhan dan produksi. Data dianalisis dengan menggunakan sidik ragam (ANOVA). Hasil penelitian dapat disimpulkan bahwa Rumput laut $K$. alvarezii varietas coklat yang dibudidaya dengan metode long line menghasilkan kuantitas terbaik.
\end{abstract}

Kata kunci: Kuantitas, Kappaphycus alvarezii, Metode Long line

\begin{abstract}
This study aims to analyze the best quantity produced from $K$. alvarezii seaweed, brown, red and green varieties cultivated by the long line method. The research was conducted from May to June 2014 at long island, Kamelanta Village, Kapontori District, Buton Regency, Southeast Sulawesi Province. The experimental design used in this study was a randomized block design (RBD) with three treatments and each treatment was repeated three times as a group based on planting distance ie land (spacing of $15 \mathrm{~m}$ from land), middle (spacing of $30 \mathrm{~m}$ from land) and inside (spacing of 45 $\mathrm{m}$ from land). Thus the experimental unit was involved as many as three units in each block so that as a whole 9 experimental units were needed. The treatments tried in this study were $K$. alvarezii seaweed, brown $(\mathrm{C})$, red $(\mathrm{M})$ and green $(\mathrm{H})$ varieties. The parameters measured were water quality, chlorophyll-a, phycoeritrin, growth rate and production. Data were analyzed using variance (ANOVA). The results of this study can be concluded that K. alvarezii Seaweed cultivated by the long line method produces the best quantity.
\end{abstract}

Keywords: Quantity, Kappaphycus alvarezii, Long line method

\footnotetext{
${ }^{1}$ Program Studi Budidaya Perairan, Universitas Dayanu Ikhsanuddin Korespondensi: Program Studi Budidaya Perairan, Fakultas Perikanan dan Ilmu Kelautan, Universitas Dayanu Ikhsanuddin, Baubau, Indonesia, Telp: +62 82322882926, email: arfanafandi05@gmail.com
} 


\section{PENDAHULUAN}

Rumput laut merupakan salah satu komoditas utama perikanan budidaya yang bernilai ekonomis tinggi dengan peluang pasar yang luas, baik nasional maupun orientasi ekspor. Rumput laut dapat dibudidayakan secara massal sehingga menjadi salah satu komoditas strategis dalam program revitalisasi perikanan yang dicanangkan Kementerian Kelautan dan Perikanan.

Kesinambungan produksi rumput laut hasil budidaya dari pengembangan usaha budidaya yang berkelanjutan diperlukan untuk memenuhi kebutuhan pasar (Utojo et al. 2007). Salah satu jenis rumput laut yang banyak dibudidayakan adalah Kappaphycus alvarezii karena proses budidayanya mudah dan tidak memerlukan modal yang besar (Amin et al. 2010).

$K$. alvarezii merupakan salah satu jenis rumput laut merah bernilai ekonomis penting yang distribusinya tergantung pada tersedianya cahaya untuk melakukan proses fotosintesis (Munoz et al. 2004). Pengaruh cahaya pada alga meliputi respons fungsional dan struktural. Respons fungsional meliputi toleransi, aktivitas metabolisme, reproduksi dan distribusi. Respons struktural meliputi perubahan ukuran, perbedaan morfologi dan perubahan sitoplasma (Dawes 1981).

Budidaya rumput laut terkendala oleh fluktuasi cahaya matahari karena intensitas cahaya dan lama penyinaran sangat bergantung pada musim. Pada saat musim tanam (musim panas) pertumbuhan rumput laut sangat baik, sementara pada saat musim hujan pertumbuhan rumput laut menurun karena rendahnya intensitas cahaya yang menyebabkan proses fotosintesis rumput laut akan terhambat. Menurut Atmadja (2007), rumput laut merah ( $K$. alvarezii) memiliki pigmen dominan fikoeretrin dan fikosianin. Fikoeritrin berperan untuk membantu menangkap cahaya yang digunakan klorofil-a dalam proses fotosintesis. Ketika rumput laut terhambat dalam membentuk pigmen klorofil- a, maka rumput laut tersebut akan membentuk fikoeritrin sebagai respons terhadap kondisi tersebut. Energi cahaya yang diserap oleh fikoeritrin selanjutnya diteruskan ke klorofila, dan rumput laut tetap dapat melakukan aktivitas fotosintesis secara optimum (Dawes 1981; Luning 1990). Berdasarkan pendapat tersebut dapat diartikan bahwa rumput laut $K$. alvarezii dapat ditanam pada saat musim hujan.

$K$. alvarezii mempunyai tiga varietas warna yang masing-masing mempunyai perbedaan dalam mengabsorbsi cahaya untuk melakukan fotosintesis. Menurut Wobeser et al. (2001) kandungan fikoeritrin dan klorofil-a pada varietas hijau dan merah cenderung sama, namun pada varietas hijau efisiensi fotosintesis dua kali lebih besar pada cahaya merah dengan panjang gelombang $600 \mathrm{~nm}$. Selanjutnya menurut Muñoz et al. (2004), K. alvarezii varietas hijau, coklat, dan merah yang dibudidayakan di Meksiko memiliki tingkat pertumbuhan berbeda; warna hijau memiliki laju pertumbuhan tertinggi yaitu sebesar $8.1 \%$ per hari, warna coklat sebesar $7.1 \%$ per hari dan warna merah $6.5 \%$.

Selain varietas rumput laut, metode budidaya juga sangat berpengaruh terhadap pertumbuhan rumput laut. Secara umum metode budidaya rumput laut yang digunakan oleh masyarakat adalah metode long line. Metode long line ini digunakan para petani karena metodenya sederhana, tahan lama ketika berada di laut, kontruksi yang sederhana dan bahannya mudah didapat serta dapat menjangkau perairan pantai yang lebih dalam jika dibandingkan dengan metode lepas dasar dan rakit apung (Sujatmiko dan Angkasa 2004). Produksi yang ditunjukan oleh metode budidaya dengan sistem long line lebih besar dibandingkan dengan metode budidaya lainnya, hal ini terkait dengan metode penanaman yang berada dipermukaan perairan, sehingga hal tersebut memberikan potensi penyerapan cahaya yang lebih baik.

Berdasarkan uraian tersebut perlu dilakukan pengkajian terhadap kuantitas tiga varietas rumput laut $K$. alverezii yang 
dibudidaya dengan metode long line pada karakteristik perairan dan musim seperti yang ada di Indonesia.

\section{METODE PENELITIAN}

Penelitian ini dilaksanakan Perairan Pulau Panjang, Desa Kamelanta, Kecamatan Kapontori, Kabupaten Buton, Provinsi Sulawesi Tenggara (Gambar 1).

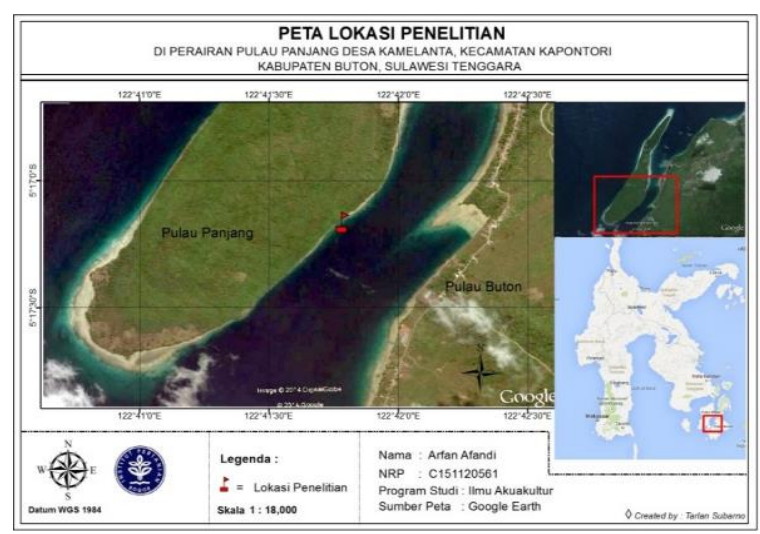

Gambar 1. Lokasi penelitian di perairan Pulau Panjang, Desa Kamelanta, Kecamatan Kapontori, Kabupaten Buton, Sulawesi Tenggara.

Rancangan percobaan yang digunakan pada penelitian ini adalah rancangan acak kelompok (RAK) dengan tiga perlakuan dan setiap perlakuan diulang tiga kali sebagai kelompok berdasarkan jarak penanaman yakni darat (jarak tanam $15 \mathrm{~m}$ dari darat), tengah (jarak tanam $30 \mathrm{~m}$ dari darat) dan dalam (jarak tanam $45 \mathrm{~m}$ dari darat). Dengan demikian unit percobaan yang dilibatkan sebanyak tiga unit pada setiap blok sehingga secara keseluruhan dibutuhkan 9 unit percobaan. Perlakuan yang dicobakan pada penelitian ini adalah rumput laut $K$. alvarezii varietas coklat (C), merah (M) dan hijau $(\mathrm{H})$.

Penempatan wadah-wadah penelitian dilakukan secara acak berdasarkan pola rancangan acak kelompok (Mattjik dan Sumertajaya 2006). Rancangan penelitian ini setelah pengacakan disajikan pada Gambar 2.

\section{Prosedur Penelitian}

\section{Budidaya Kapaphycus alvarezii}

Metode budidaya rumput laut yang digunakan dalam penelitian ini adalah metode long line. Metode long line adalah metode budidaya dengan menggunakan tali panjang yang dibentangkan pada perairan laut. Dalam penelitian ini menggunakan tali ris sebagai tempat diikatkannya bibit rumput laut.

Bibit rumput laut jenis $K$. alvarezii diperoleh dari perairan desa Kamelanta, Sulawesi Tenggara. Bibit disiapkan setelah konstruksi long line telah siap. Hal ini dimaksudkan ketika persiapan bibit usai, bibit rumput laut dapat segera ditanam sehingga tidak layu dan mati. Bibit diseleksi kembali sesuai dengan kriteria bibit yang berkualitas baik. Bibit rumput laut yang baik berasal dari tanaman induk yang sehat, segar dan bebas penyakit. Ciri-ciri bibit rumput laut $K$. alvarezii yang baik adalah apabila dipegang terasa elastis, mempunyai cabang yang banyak, ujungnya berwarna kuning kemerahmerahan, batang tebal dan bebas dari tanaman yang lain.

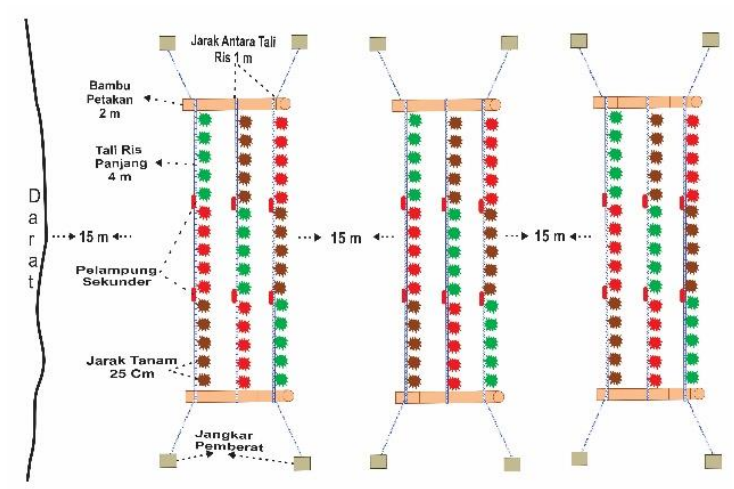

Gambar 2. Konstruksi budidaya metode long line

Rumput laut $K$. alvarezii diikat simpul terbuka pada tali ris. Pengikatan dengan simpul terbuka dimaksudkan agar memudahkan ketika panen. Penataan unit percobaan terdiri dari tiga kelompok yakni darat (15 $\mathrm{m}$ dari darat), tengah (30 $\mathrm{m}$ dari darat) dan dalam (45 $\mathrm{m}$ dari darat). Pada setiap kelompok diwakili oleh setiap jenis $K$. alvarezii yang diberi jarak tanam $25 \mathrm{~cm}$ dan bobot bibit 100 gram. Jarak tanam dan bobot 
bibit tersebut sangat baik untuk pertumbuhan $K$. alvarezii karena mempengaruhi lalu lintas pergerakan air juga akan menghindari terkumpulnya kotoran pada talus yang akan membantu pengudaraan, dengan demikian proses fotosintesis yang diperlukan untuk pertumbuhan rumput laut dapat berlangsung serta mencegah adanya fluktuasi yang besar terhadap salinitas maupun suhu air (Afandi 2010).

\section{Pengontrolan dan Panen}

Setiap dua kali dalam seminggu dilakukan pengontrolan untuk menjaga kondisi bibit yang ditanam tetap dalam keadaan baik. Pengontrolan yang dilakukan adalah pengontrolan terhadap kotoran, endapan dan tumbuhan liar yang menempel. Selain itu, pengontrolan juga dilakukan terhadap konstruksi media tanam berupa tali yang terlepas, pelampung dan keadaan jangkar.

Parameter fisik dan kimia perairan juga diukur pada saat awal penanaman dan setiap lima belas hari sekali yaitu hari ke 15, 30 dan 45 meliputi suhu, kecepatan arus, kecerahan, salinitas, $\mathrm{pH}, \mathrm{DO}$, nitrat dan fosfat.

Waktu yang diperlukan oleh rumput laut untuk mencapai tingkat kandungan bahan utama maksimal merupakan patokan dalam menentukan waktu panen. Rumput laut $K$. alvarezii memiliki kandungan karaginan yang optimal setelah berumur 45 hari (Widyastuti 2010). Setelah dipanen rumput laut dicuci dengan menggunakan air laut, untuk menghilangkan kotoron yang menempel dan selanjutnya ditimbang untuk mengetahui bobot basahnya. Rumput laut kemudian dimasukkan ke dalam kantong plastik untuk selanjutnya dibawa ke tempat penjemuran. Selama penjemuran berlangsung, rumput laut dijaga agar terhindar dari air hujan.

\section{Parameter Uji}

\section{Parameter Kualitas air}

Tabel 1. Parameter kualitas air

\begin{tabular}{lll}
\hline $\begin{array}{l}\text { Jenis } \\
\text { parameter }\end{array}$ & Alat ukur & Satuan \\
\hline $\begin{array}{l}\text { Suhu } \\
\text { Kecepatan }\end{array}$ & $\begin{array}{l}\text { Termometer } \\
\text { Curus }\end{array}$ & $\begin{array}{l}{ }^{\circ} \mathrm{C} \\
\mathrm{cm} / \mathrm{detik}\end{array}$ \\
$\begin{array}{l}\text { Kecerahan } \\
\text { Salinitas }\end{array}$ & $\begin{array}{l}\text { Secchi disk } \\
\text { Hand refraktometer }\end{array}$ & $\mathrm{M}$ \\
$\mathrm{pH}$ & $\mathrm{pH}$ meter & \\
Oksigen & DO meter & $\mathrm{mg} / \mathrm{L}$ \\
terlarut & & \\
Nitrat & Spektrofotometer & $\mathrm{mg} / \mathrm{L}$ \\
Fosfat & Spektrofotometer & $\mathrm{mg} / \mathrm{L}$ \\
\hline
\end{tabular}

\section{Kandungan Klorofil-a}

Kandungan klorofil-a dianalisis melalui ekstraksi $2 \mathrm{~g}$ talus (thallus) dicincang dengan pasir kuarsa hingga halus, kemudian ditambahkan $10 \mathrm{ml}$ aseton $90-100 \%$. Wadah selanjutnya dibungkus dengan aluminium foil dan didinginkan selama semalam. Kemudian disentrifugasi $1.400 \mathrm{x}$ selama 2 menit. Supernatan diukur menggunakan spektrofotometer (Jeffrey dan Humphrey 1975).

Klorofil-a $(\mathrm{mg} / \mathrm{L})=11.93 \times(\lambda 664)-1.93 \times$ ( $\lambda 647)$

\section{Kandungan Fikoeritrin}

Kandungan fikoeritrin dianalisis melalui ekstraksi $2 \mathrm{~g}$ talus dicincang dengan pasir kuarsa hingga halus, kemudian ditambahkan $10 \mathrm{ml} 0.1 \mathrm{M}$ bufer fosfat dan $\mathrm{pH}$ 6.8 selama semalam. Selanjutnya disentrifugasi 1000x selama 2 menit sebelum diukur dengan spektrofotometer (Evans 1988).

Fikoeritrin $(\mathrm{mg} / \mathrm{L})=\left[\begin{array}{l}(\lambda 564-\lambda 592)- \\ -\end{array}\right.$ $(\lambda 455-\lambda 592) \times 0.20] \times 0.12$ 


\section{Laju Pertumbuhan}

Angka laju pertumbuhan (growth rate) rumput laut dihitung dengan menggunakan rumus Zonneveld et al. (1991).

$$
L P=\frac{W t-W o}{t}
$$

Keterangan :

$\mathrm{LP}=$ Laju pertumbuhan $(\mathrm{g} / \mathrm{hari})$

$\mathrm{W}_{\mathrm{t}}=$ bobot rumput laut pada akhir pemeliharaan $(\mathrm{g})$

$\mathrm{W}_{0}=$ bobot rumput laut pada awal pemeliharaan $(\mathrm{g})$

$\mathrm{t}=$ lama pemeliharaan (hari)

\section{Produksi Rumput Laut}

Pengukuran produksi dilakukan ketika rumput laut berumur 45 hari. Parameter yang diamati adalah biomassa akhir dari tanaman. Menurut Patadjai (2007) produksi dihitung sebagai berikut :

$$
\mathrm{P}=\frac{\mathrm{W}_{\mathrm{t}}-\mathrm{W}_{0}}{\mathrm{~A}}
$$

Keterangan :

$\mathrm{P}=$ Produksi rumput laut $\left(\mathrm{g} / \mathrm{m}^{2}\right)$

$\mathrm{W}_{\mathrm{t}}=$ Biomassa akhir rumput laut $(\mathrm{g})$

$\mathrm{W}_{0}=$ Biomassa awal rumput laut $(\mathrm{g})$

$\mathrm{A}=$ Luas area pemeliharaan $\left(\mathrm{m}^{2}\right)$

\section{HASIL DAN PEMBAHASAN}

\section{Kualitas Air}

Hasil Parameter kualitas air seperti suhu, kecepatan arus, kecerahan, salinitas, $\mathrm{pH}$, oksigen terlarut, nitrat, dan fosfat pada tiga kelompok (darat, tengah, dan dalam) pada penelitian ini disajikan pada Tabel 2.

Suhu perairan selama penilitian berkisar antara $28-31^{\circ} \mathrm{C}$ untuk semua kelompok, hal ini menunjukan bahwa kisaran suhu masih dalam tahap yang memungkinkan untuk pertumbuhan rumput laut. Persyaratan suhu perairan yang optimum untuk budidaya $K$. alvarezii yaitu antara $27-30^{\circ} \mathrm{C}$ dan dengan fluktuasi suhu yang rendah antara malam dan siang hari (SNI 2010). Sulma dan Manoppo (2008), mengungkapkan bahwa syarat kualitas perairan untuk budidaya, suhu yang baik untuk pertumbuhan rumput laut adalah $24-30^{\circ} \mathrm{C}$. Suhu yang tinggi dapat menyebabkan protein mengalami denaturasi, serta dapat merusak enzim dan membran sel yang bersifat labil terhadap suhu yang tinggi. Pada suhu yang rendah, protein dan lemak membran dapat mengalami kerusakan sebagai akibat terbentuknya kristal di dalam sel (Mamang 2008). Suhu perairan erat kaitannya dengan laju fotosintesis disamping cahaya dan kandungan nutrien di perairan (Dawes 1981).

Kecepatan arus yang diukur selama penelitian berkisar 9.7-19 cm/detik pada setiap kelompok dan masih berada dibawah kondisi optimum, namun masih berada pada kisaran kelayakan budidaya rumput laut. Kecepatan arus yang ideal untuk budidaya rumput laut berkisar antara $5-50 \mathrm{~cm} /$ detik dengan nilai optimum 20-40 $\mathrm{cm} /$ det (SNI 2010). Arus dapat memberi pengaruh baik dan pengaruh buruk dalam kegiatan budidaya rumput laut. Pengaruh baiknya yaitu rumput laut memerlukan arus untuk membantu ketersediaan pasokan nutrien. Sinaga (1999) mengemukakan bahwa semakin kuat arus suatu perairan maka pertumbuhan alga laut akan semakin cepat karena difusi nutrien ke dalam sel talus semakin banyak, sehingga metabolisme dipercepat. Pengaruh buruknya yaitu jika arus terlalu besar akan merusak rumput laut tersebut. Lokasi untuk budidaya $K$. alvarezii harus terlindung dari arus dan hempasan ombak yang besar. Apabila hal ini terjadi, arus dan ombak akan merusak dan menghanyutkan tanaman.

Selama pengamatan kecerahan perairan di lokasi penelitian menunjukkan bahwa tingkat kecerahan setiap kelompok masih dalam kisaran optimum yaitu 3-6 m, sehingga masih sangat baik dalam mendukung pertumbuhan $K$. alvarezii. Nilai kecerahan yang ideal untuk budidaya rumput laut adalah $>1$ meter (SNI 2010). Cahaya matahari merupakan sumber energi dalam proses fotosintesis. Kecerahan perairan sangat berpengaruh terhadap penetrasi cahaya matahari yang masuk kedalam perairan. Tinggi rendahnya nilai kecerahan suatu 
perairan sangat dipengaruhi oleh tinggi rendahnya kekeruhan perairan. Selama berlangsungnya proses fotosintesis terjadi pembentukan bahan organik yang diperlukan bagi pertumbuhan dan perkembangan normal. Nilai kecerahan dari suatu perairan sangat dipengaruhi oleh keadaan cuaca, waktu pengukuran, kekeruhan dan padatan tersuspensi. Kecerahan perairan menentukan jumlah intensitas sinar matahari atau cahaya yang masuk ke dalam perairan sangat ditentukan oleh warna perairan, kandungan bahan-bahan organik maupun anorganik tersuspensi di perairan, kepadatan plankton, jasad renik dan detritus. Kekeruhan merupakan faktor pembatas bagi proses fotosintesis dan produksi primer perairan karena mempengaruhi penetrasi cahaya matahari (Mamang 2008). dalam hal ini adalah laju fotosintesis $K$. alvarezii (Dawes 1981). Semakin tinggi kadar garam (salinitas) maka makin besar pula tekanan osmotik pada air. Selain itu salinitas juga berhubungan dengan proses osmoregulasi dalam tubuh organisme. Apabila salinitas rendah maka akan merusak rumput laut yang ditandai dengan timbulnya warna putih pada bagian ujung-ujung tanaman (Iksan 2005).

Nilai pH untuk lokasi penelitian berada pada kisaran normal yaitu 7.3-7.8 pada setiap kelompok. Supit (1989) menyatakan bahwa hampir seluruh alga menyukai kisaran pH 6.8-9.6. Kisaran $\mathrm{pH}$ yang optimum untuk menunjang kelangsungan hidup $K$. alvarezii adalah 7-8.5 (SNI 2010).

Tabel 2. Kualitas air selama penelitian

\begin{tabular}{lccccc}
\hline \multirow{2}{*}{ Parameter } & \multicolumn{3}{c}{ Kelompok* } & \multicolumn{2}{c}{ SNI (2010) } \\
\cline { 2 - 6 } & Darat & Tengah & Dalam & Kisaran & Optimum \\
\hline Suhu $\left({ }^{0} \mathrm{C}\right)$ & $28-31$ & $29-30$ & $28-30$ & $20-33$ & $27-30$ \\
Kecepatan arus (cm/detik) & $9.7-12.15$ & $14.11-18.18$ & $10.86-19$ & $5-50$ & $20-40$ \\
Kecerahan $(\mathrm{m})$ & $3.0-4.0$ & $4.5-6$ & $4.5-6$ & $1-5$ & $>3$ \\
Salinitas $(\% \circ)$ & $28-30$ & $30-32$ & $30-32$ & $15-38$ & $28-34$ \\
$\mathrm{pH}$ & $7.3-7.6$ & $7.4-7.6$ & $7.5-7.8$ & $6,0-9,0$ & $7.5-8,0$ \\
Oksigen terlarut $(\mathrm{mg} / \mathrm{L})$ & $6.7-7$ & $7-7.8$ & $7-8.1$ & $1-15$ & $3-8$ \\
Nitrat $(\mathrm{mg} / \mathrm{L})$ & $0.89-1.85$ & $0.99-1.32$ & $0.98-1.30$ & $1.0-3.2$ & $1.5-2.5$ \\
Fosfat $(\mathrm{mg} / \mathrm{L})$ & $0.055-0.062$ & $0.055-0.063$ & $0.065-0.071$ & $0.021-0.100$ & $0.050-0.075$ \\
\hline
\end{tabular}

*Darat = jarak tanam $15 \mathrm{~m}$ dari darat; tengah $=$ jarak tanam $30 \mathrm{~m}$ dari darat; dalam $=$ jarak tanam $45 \mathrm{~m}$ dari darat.

Kisaran salinitas pada lokasi penelitian menunjukkan kisaran yang masih sangat baik dalam mendukung pertumbuhan K. alvarezii yaitu berkisar $28-32 \%$ pada setiap kelompok. Salinitas untuk pertumbuhan K. alvarezii yang optimum berkisar $28-34 \%$ (SNI 2010). Pertumbuhan rumput laut dipengaruhi oleh salinitas atau kadar garam. Ada dua golongan rumput laut berdasarkan toleransi salinitas, yaitu stenohalin (hidup dan tumbuh pada perairan dengan kisaran salinitas yang sempit), serta euryhalin (hidup dan tumbuh pada perairan dengan kisaran salinitas yang lebar) (Bahaluddin 2006). Lokasi budidaya harus jauh dari limpahan air tawar (muara sungai) agar terhindar dari fluktuasi salinitas yang tinggi, karena dapat mempengaruhi proses fisiologis, termasuk
Perairan laut tidak memiliki fluktuasi $\mathrm{pH}$ atau dengan kata lain nilai $\mathrm{pH}$ hampir selalu berada pada kisaran normal sebagai akibat air laut merupakan larutan penyangga. Kisaran nilai oksigen terlarut di lokasi penelitian berkisar antara $6.7-8.1 \mathrm{mg} / \mathrm{L}$ artinya bahwa nilai oksigen terlarut pada setiap kelompok berada pada kondisi yang sangat baik. Oksigen terlarut yang layak untuk budidaya rumput laut berkisar antara 1-15 $\mathrm{mg} / \mathrm{L}$ dengan nilai optimum $3-8 \mathrm{mg} / \mathrm{L}$ (SNI 2010). Baku mutu DO untuk rumput laut adalah lebih dari $5 \mathrm{mg} / \mathrm{L}$, hal ini berarti jika oksigen terlarut dalam perairan mencapai 5 $\mathrm{mg} / \mathrm{L}$ maka metabolisme rumput laut dapat berjalan dengan optimal (Sulistijo dan Atmadja 1996). Oksigen terlarut sangat 
penting karena sangat dibutuhkan oleh organisme air untuk metabolisme.

Kisaran nilai nitrat di lokasi penelitian berkisar antara 0.89-1.85 mg/L. Nilai nitrat yang diukur pada setiap kelompok selama penelitian menunjukkan nilai yang sudah cukup baik, hal ini dikarenakan terdapat input nutrien melalui hujan pada saat melakukan pengambilan sampel. Kisaran nitrat yang optimum untuk menunjang kelangsungan hidup $K$. alvarezii adalah $1.5-2.5 \mathrm{mg} / \mathrm{L}$ (SNI 2010). Menurut Kepmen No. 51/MENKLH (2004), kisaran nilai nitrat untuk budidaya rumput laut adalah $0.1-0.7$ tergolong sangat baik; $0.01-<0$ tergolong baik dan $<0.01$ kurang baik. Rumput laut memerlukan unsur hara sebagai bahan baku dalam proses fotosintesis. Unsur utama yang dibutuhkan oleh rumput laut adalah fosfor dalam bentuk fosfat $\left(\mathrm{PO}_{4}\right)$ dan nitrogen dalam bentuk nitrat $\left(\mathrm{NO}_{3}\right)$ untuk kelangsungan hidupnya (Effendi 2000). Nitrogen adalah salah satu unsur utama penyusun sel organisme yaitu dalam proses pembentukan protoplasma. Nitrogen seringkali berada dalam jumlah yang terbatas di perairan, terutama di daerah beriklim tropis. Kekurangan nitrat dalam perairan dapat menghambat pertumbuhan tanaman akuatik, walaupun unsur hara lain berada dalam jumlah yang melimpah. Alga mempunyai kecenderungan untuk lebih dahulu menggunakan $\mathrm{N}$-anorganik dan urea, sedangkan N-organik terlarut hanya akan digunakan jika sumber atau bentuk nitrogen lain konsentasinya sudah sangat rendah (Patadjai 1993).
Konsentrasi fosfat yang diukur selama penelitian pada setiap kelompok berkisar antara 0,055-0,071 mg/L menunjukkan bahwa nilai konsentrasi fosfat tergolong baik untuk pertumbuhan rumput laut $K$. alvarezii. Kisaran fosfat yang optimum untuk menunjang kelangsungan hidup $K$. alvarezii adalah 0.050-0.075 mg/L (SNI 2010). Menurut Kepmen No. 51/MENKLH (2004), kisaran nilai fosfat untuk budidaya rumput laut adalah $0.1-0.2$ tergolong sangat baik; $0.02-<0.1$ tergolong baik dan $<0.02$ kurang baik. Unsur utama lain yang dibutuhkan rumput laut selain nitrat yaitu fosfat. Fosfat merupakan unsur hara dalam perairan berkarang yang bersumber dari aliran air, buangan kotoran hewan, sumbangan sedimen dari terumbu, mangrove dan lamun serta sumbangan dari alga zooxanthella (Romimohtarto dan Juwana 2001). Unsur fosfor merupakan penyusun ikatan pirofosfat dari adenosin trifosfat (ATP) yang kaya energi dan merupakan bahan bakar bagi semua kegiatan dalam semua sel hidup serta merupakan penyusun sel yang penting. Senyawa fosfat merupakan penyusun fosfolipida yang penting sebagai penyusun membran dan terdapat dalam jumlah besar. Energi yang dibebaskan dari hidrolisis pirofosfat dan berbagai ikatan fosfat organik digunakan untuk mengendalikan berbagai reaksi kimia (Patadjai 1993). Kandungan fosfor dalam sel alga mempengaruhi laju serapan fosfat, yaitu berkurang sejalan dengan meningkatnya kandungan fosfat dalam sel.

Tabel 3. Hasil uji parameter penelitian

\begin{tabular}{lccc}
\hline & \multicolumn{3}{c}{ Nilai } \\
\cline { 2 - 4 } Parameter & Varietas Coklat & Varietas Merah & Varietas Hijau \\
\hline Pigmen : & & & \\
Klorofil-a $(\mathrm{mg} / \mathrm{L})$ & $0.244 \pm 0.007^{\mathrm{a}}$ & $0.182 \pm 0.006^{\mathrm{b}}$ & $0.181 \pm 0.007^{\mathrm{b}}$ \\
Fikoeritrin $(\mathrm{mg} / \mathrm{L})$ & $0.012 \pm 0.001^{\mathrm{a}}$ & $0.006 \pm 0.001^{\mathrm{b}}$ & $0.005 \pm 0.00^{\mathrm{b}}$ \\
\hline Kuantitas : & & \\
Laju pertumbuhan (g/hari) & $5.494 \pm 0.92^{\mathrm{a}}$ & $1.691 \pm 0.16^{\mathrm{b}}$ & $2.556 \pm 0.57^{\mathrm{b}}$ \\
Produksi $\left(\mathrm{g} / \mathrm{m}^{2}\right)$ & $1462.5 \pm 99.22^{\mathrm{a}}$ & $337.50 \pm 37.50^{\mathrm{b}}$ & $506.25 \pm 104.40^{\mathrm{b}}$ \\
\hline - Angka-angka pada baris yang sama dengan huruf sama tidak menunjukkan perbedaan signifikan pada \\
taraf uji $5 \%$ (uji Tukey) \\
• Nilai merupakan rata-rata \pm standar deviasi
\end{tabular}


Parameter kualitas air seperti suhu, kecepatan arus, kecerahan, salinitas, $\mathrm{pH}$, oksigen terlarut, nitrat dan fosfat pada ketiga kelompok (darat, tengah, dan dalam) pada penelitian ini masih sesuai dengan kelayakan lingkungan perairan untuk lokasi budidaya rumput laut.

\section{Kuantitas Rumput Laut}

Pada analisis ragam (ANOVA) menunjukkan bahwa perlakuan varietas yang berbeda (coklat, merah, dan hijau) memberikan pengaruh yang signifikan terhadap kuantitas sedangkan pada kelompok yang berbeda (darat, tengah, dan dalam) tidak memberikan pengaruh yang signifikan terhadap kuantitas rumput laut $K$. alvarezii.

Hasil yang diperoleh dari beberapa parameter uji berupa klorofil-a, fikoeritrin, laju pertumbuhan dan produksi disajikan pada Tabel 3.

\section{Kandungan Klorofil-a dan Fikoeritrin}

Kandungan klorofil-a (Tabel 3) pada K. alvarezii varietas coklat $(0.244 \pm 0.007$ $\mathrm{mg} / \mathrm{L})$ secara signifikan $(\mathrm{P}<0.05)$ lebih tinggi dari varietas merah dan hijau, sedangkan varietas merah $(0.182 \pm 0.006 \mathrm{mg} / \mathrm{L})$ tidak berbeda signifikan $(\mathrm{P}>0.05)$ dengan varietas hijau $(0.181 \pm 0.007 \quad \mathrm{mg} / \mathrm{L})$. Kandungan fikoeritrin antar perlakuan (Tabel 3) menunjukkan perbedaan signifikan $(\mathrm{P}<0.05)$, yaitu kandungan fikoeritrin varietas coklat $(0.012 \pm 0.001 \mathrm{mg} / \mathrm{L})$ lebih tinggi dari perlakuan varietas merah dan hijau. Fikoeritrin pada varietas merah $(0.006 \pm 0.001$ $\mathrm{mg} / \mathrm{L})$ tidak berbeda signifikan $(\mathrm{P}>0.05)$ dengan varietas hijau $(0.005 \pm 0.00 \mathrm{mg} / \mathrm{L})$.

Tingginya kandungan fikoeritrin pada K. alvarezii varietas coklat (Gambar 3) dikarenakan kurangnya pencahayaan selama berlangsungnya penelitian (musim hujan). Salisbury dan Ross (1992) menyatakan bahwa pigmen pelengkap (fikoeritrin) pada rumput laut berfungsi membantu penyerapan cahaya pada saat kondisi stres cahaya. Tingginya kandungan klorofil-a pada varietas coklat (Gambar 3) terkait dengan tingginya kandungan fikoeritrin yang memacu jenis coklat untuk membentuk klorofil-a agar aktivitas fotosintesis bisa maksimum. Ketika rumput laut kesulitan dalam membentuk pigmen klorofil-a, maka rumput laut tersebut akan membentuk fikoeritrin sebagai respons terhadap kondisi tersebut, sehingga energi cahaya yang diserap oleh fikoeritrin selanjutnya diteruskan ke klorofil-a, dan rumput laut tetap dapat melakukan aktivitas fotosintesis secara optimum (Dawes 1981; Luning 1990). Kandungan klorofil-a (y) berkaitan dengan kandungan fikoeritrin (x) tiga varietas rumput laut $K$. alvarezii, mengikuti persamaan $\mathrm{y}=0.0952 \mathrm{x}-0.0119$ dengan $\mathrm{R}^{2}=0.8522$ (Gambar 4).

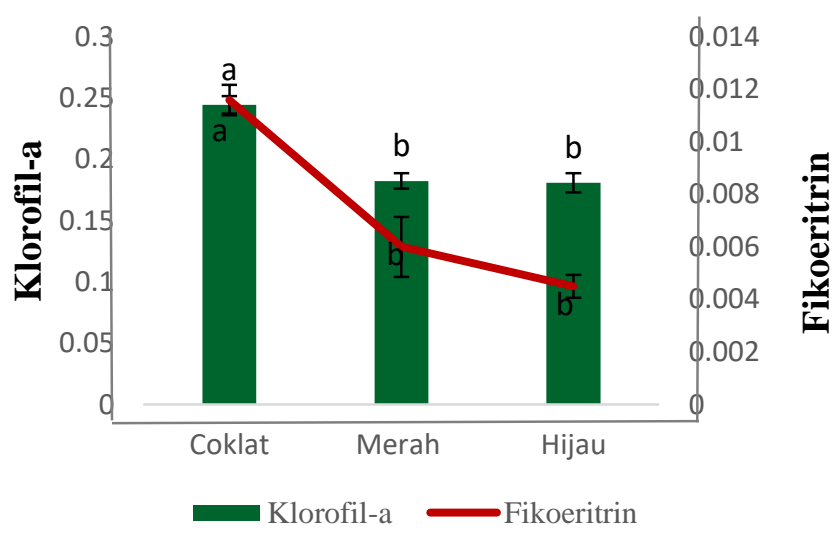

Gambar 3. Kandungan klorofil-a dan fikoeritrin tiga varietas rumput laut $K$. alvarezii.

Tingginya kandungan klorofil-a pada $K$. alvarezii varietas coklat terkait dengan tingginya kandungan pigmen. Tingginya konsentrasi pigmen pada $K$. alvarezii juga dapat terlihat dari morfologi (warna) talus yang dimiliki. Semakin tinggi konsentrasi pigmen, warna talus yang dimiliki rumput laut akan semakin pekat atau gelap (Rusdani 2013). Berdasarkan pendapat tersebut dapat diartikan bahwa $K$. alvarezii varietas coklat memiliki warna yang lebih pekat dibanding varietas merah dan hijau. Dengan demikian dapat dikatakan bahwa varietas coklat memiliki kandungan pigmen yang tinggi. Kandungan pigmen yang tinggi akan mempengaruhi daya serap cahaya oleh 
tanaman. Besarnya radiasi cahaya yang dapat diserap oleh tanaman dipengaruhi juga oleh besarnya kandungan pigmen yang terdapat di dalam kloroplas tanaman (Packer 2009).

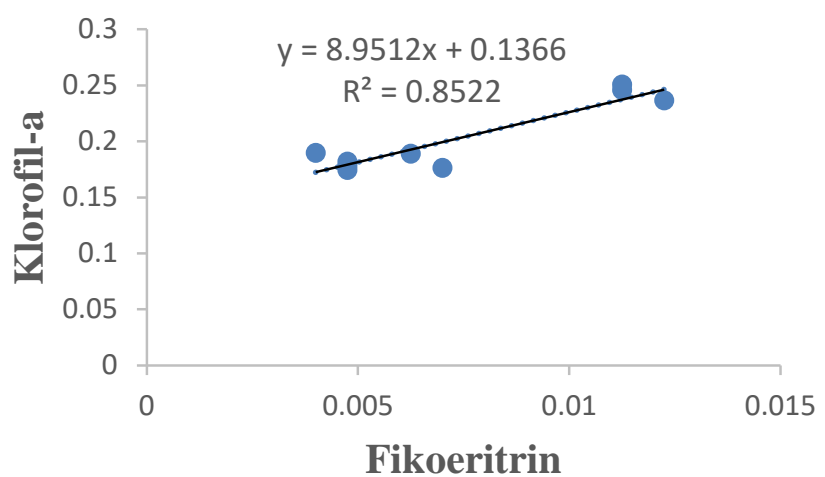

Gambar 4. Kurva hubungan klorofil-a dan fikoeritrin rumput laut $K$. alvarezii.

\section{Laju Pertumbuhan K. Alvarezii}

Nilai laju pertumbuhan (Tabel 3) pada K. alvarezii varietas coklat $(5.494 \pm 0.92$ $\mathrm{g} / \mathrm{hari}$ ) lebih tinggi dan menunjukkan perbedaan signifikan $(\mathrm{P}<0.05)$ dengan varietas merah dan varietas hijau. Laju pertumbuhan pada $K$. alvarezii varietas merah $(1.691 \pm 0.16$ $\mathrm{g} /$ hari) tidak berbeda signifikan $(\mathrm{P}>0.05)$ dengan perlakuan varietas hijau $(2.556 \pm 0.57$ $\mathrm{g} /$ hari).

Laju pertumbuhan rumput laut $K$. alvarezii varietas coklat menunjukkan nilai yang lebih tinggi dibandingkan varietas hijau dan merah (Gambar 5). Hal ini diakibatkan oleh tingginya kandungan klorofil-a dan fikoeritrin pada varietas coklat, sehingga pertumbuhan varietas coklat lebih baik jika dibandingkan dengan varietas merah dan hijau. Hal ini terkait dengan kemampuan varietas coklat untuk melakukan proses fotosintesis dengan tingginya kandungan klorofil-a dan fikoeritrin. Proses fotosintesis tersebut akan mempengaruhi pertumbuhan rumput laut, karena proses fotosintesis menghasilkan karbohidrat sebagai produk akhirnya. Fotosintesis merupakan proses metabolik, dengan cara menangkap spektrum sinar tampak dan digunakan untuk mengkonversi karbon anorganik dalam bentuk karbondioksida $\left(\mathrm{CO}_{2}\right)$ dan air $\left(\mathrm{H}_{2} \mathrm{O}\right)$ menjadi karbon organik dan molekul oksigen $\left(\mathrm{O}_{2}\right)$. Kandungan klorofil-a (x) dan fikoeritrin (x) berkaitan dengan laju pertumbuhan (y) tiga varietas rumput laut $K$. alvarezii, mengikuti persamaan klorofil-a yaitu $\mathrm{y}=49.673 \mathrm{x}-$ 6.809 dengan $\mathrm{R}^{2}=0.7717$ dan fikoeritrin yaitu $\mathrm{y}=478.26 \mathrm{x}-0.2736$ dengan $\mathrm{R}^{2}=0.7609$ (Gambar 6).

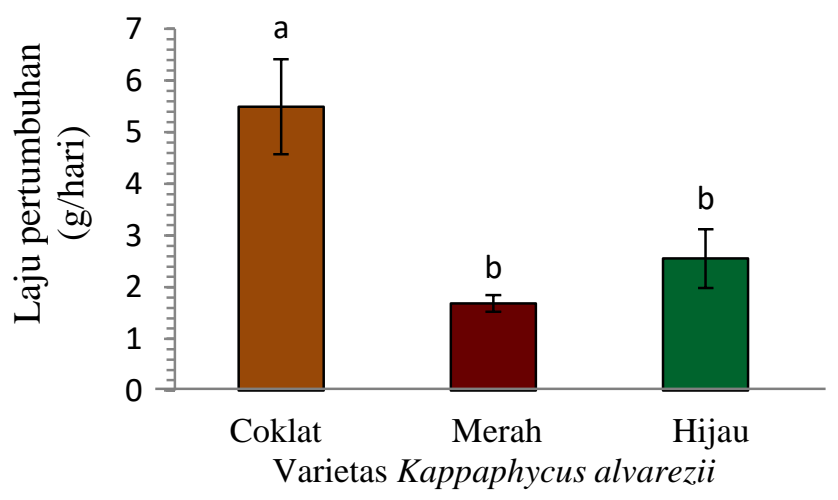

Gambar 5. Laju pertumbuhan tiga varietas rumput laut $K$. alvarezii

Pengaruh pencahayaan dan lama penyinaran pada saat penilitian memacu pembentukan klorofil-a dan fikoeritrin sebagai bentuk adaptasi kromatik. Salah satu faktor yang mempengaruhi pencahayaan dan lama penyinaran yaitu musim, Pada saat penelitian berlangsung kurangnya pencahayaan dan lama penyinaran disebabkan tingginya curah hujan yang berdampak negatif pada pertumbuhan $K$. alvarezii. Hal tersebut terjadi pada varietas merah dan hijau yang memiliki laju pertumbuhan yang lebih rendah dari varietas coklat. Hal ini dikarenakan varietas coklat memiliki kandungan fikoeritrin yang lebih tinggi untuk menyerap cahaya matahari yang selanjutnya akan diteruskan ke klorofil-a untuk melakukan fotosintesis dibandingkan varietas merah dan hijau. Kekurangan intensitas cahaya yang diterima $K$. alvarezii dapat menghambat proses fotosintesis sehingga berdampak negatif bagi laju pertumbuhan dan kualitas karaginannya (Doty 1985). Lebih lanjut menurut Paula dan Pereira (2003), ada pengaruh musiman terhadap 
pertumbuhan rumput laut yaitu pertumbuhan tertinggi diperoleh pada musim panas (Januari - Mei) sedangkan pertumbuhan terendah diperoleh pada musim dingin (Juni Desember).
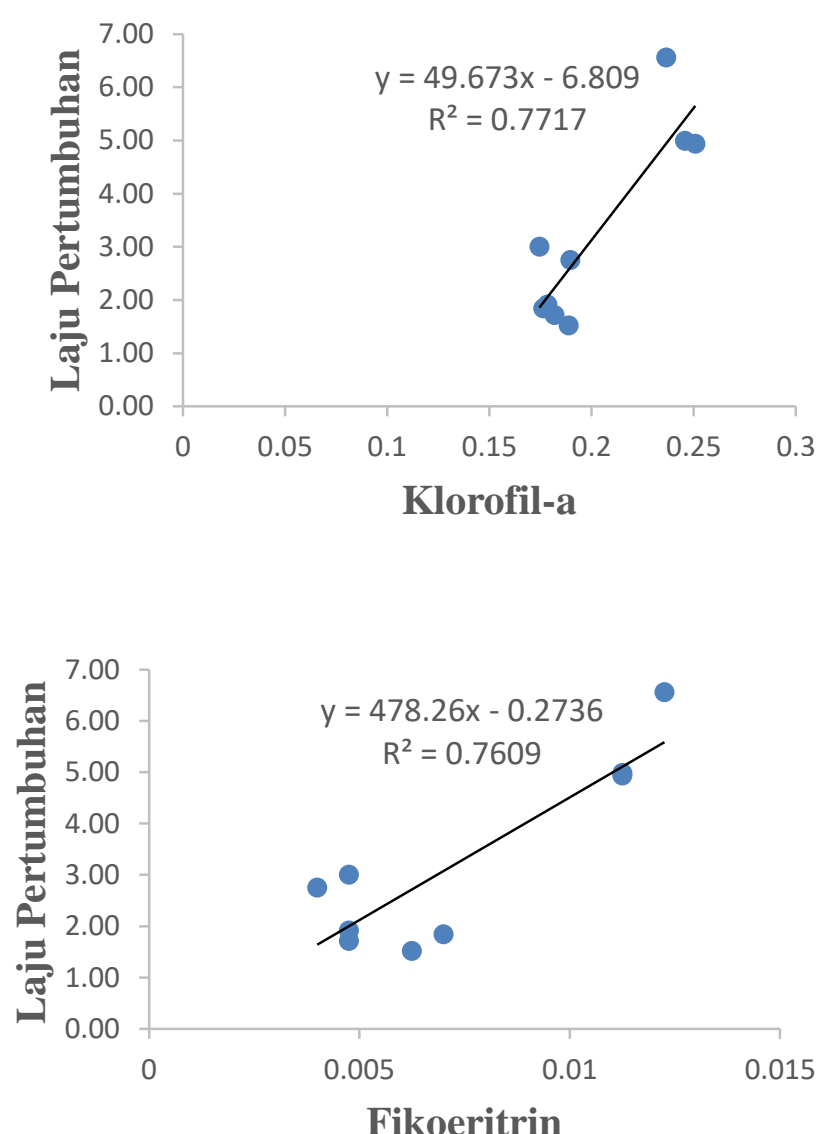

Gambar 6. Kurva hubungan klorofil-a dan fikoeritrin dengan laju pertumbuhan rumput laut $K$. alvarezii.

\section{Produksi}

Hasil penelitian (Tabel 3) menunjukkan bahwa nilai produksi rumput laut K.alvarezii varietas coklat berbeda signifikan $(\mathrm{P}<0.05)$ dengan varietas merah dan hijau, antara varietas merah dengan varietas hijau tidak menunjukkan perbedaan signifikan $(\mathrm{P}>0.05)$. Produksi pada varietas coklat lebih tinggi $\left(1462.5 \pm 99.22 \mathrm{~g} / \mathrm{m}^{2}\right)$ dibanding varietas hijau $\left(506.25 \pm 104.40 \mathrm{~g} / \mathrm{m}^{2}\right)$ dan varietas merah $\left(337.50 \pm 37.50 \mathrm{~g} / \mathrm{m}^{2}\right)$.

Laju pertumbuhan yang tinggi menyebabkan produksi rumput laut $K$. alvarezii tinggi. Hal ini terlihat bahwa produksi rumput laut $K$. alvarezii varietas coklat lebih tinggi dibandingkan dengan produksi rumput laut $K$. alvarezii varietas hijau dan $K$. alvarezii varietas merah (Gambar 7). Perbedaan produksi dari tiga varietas rumput laut $K$. alvarezii dipengaruhi tingginya kandungan klorofil-a dan fikoeritrin. Kandungan klorofil-a (x) dan fikoeritrin (x) berkaitan dengan produksi (y) tiga varietas rumput laut $K$. alvarezii mengikuti persamaan untuk klorofil-a yaitu $\mathrm{y}=15669 \mathrm{x}-$ 2403.3 dengan $\mathrm{R}^{2}=0.8941$ dan fikoeritrin yaitu $\mathrm{y}=147183 \mathrm{x}-314.68$ dengan $\mathrm{R}^{2}=$ 0.8391 (Gambar 8).

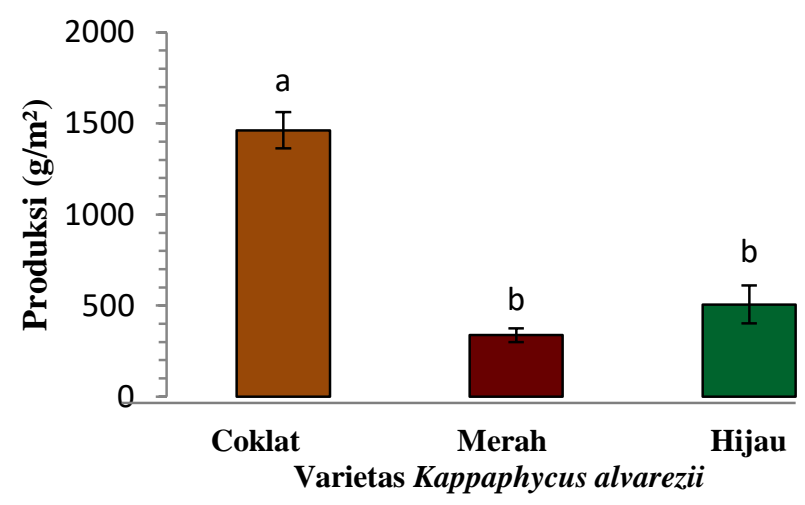

Gambar 7. Produksi tiga varietas rumput laut K. alvarezii

Tingginya produksi pada varietas coklat terkait dengan jumlah klorofil-a dan fikoeritrin yang lebih tinggi dibandingkan varietas hijau dan merah. Rendahnya produksi pada varietas hijau dan merah disebabkan oleh rendahnya kandungan klorofil-a dan fikoeritrin. Hal ini terkait dengan kemampuan klorofil-a dan fikoeritrin dalam menyerap cahaya untuk proses fotosintesis. Jika fotosintesis dapat berlangsung baik maka pertumbuhan akan baik yang akhirnya akan meningkatkan produksi. Hal ini sesuai dengan pendapat Rusdani (2013), intensitas cahaya yang diterima akan mempengaruhi produksi rumput laut. Semakin tinggi intensitas cahaya dan penyerapan cahaya yang diterima maka akan meningkatkan bobot panen rumput laut. 

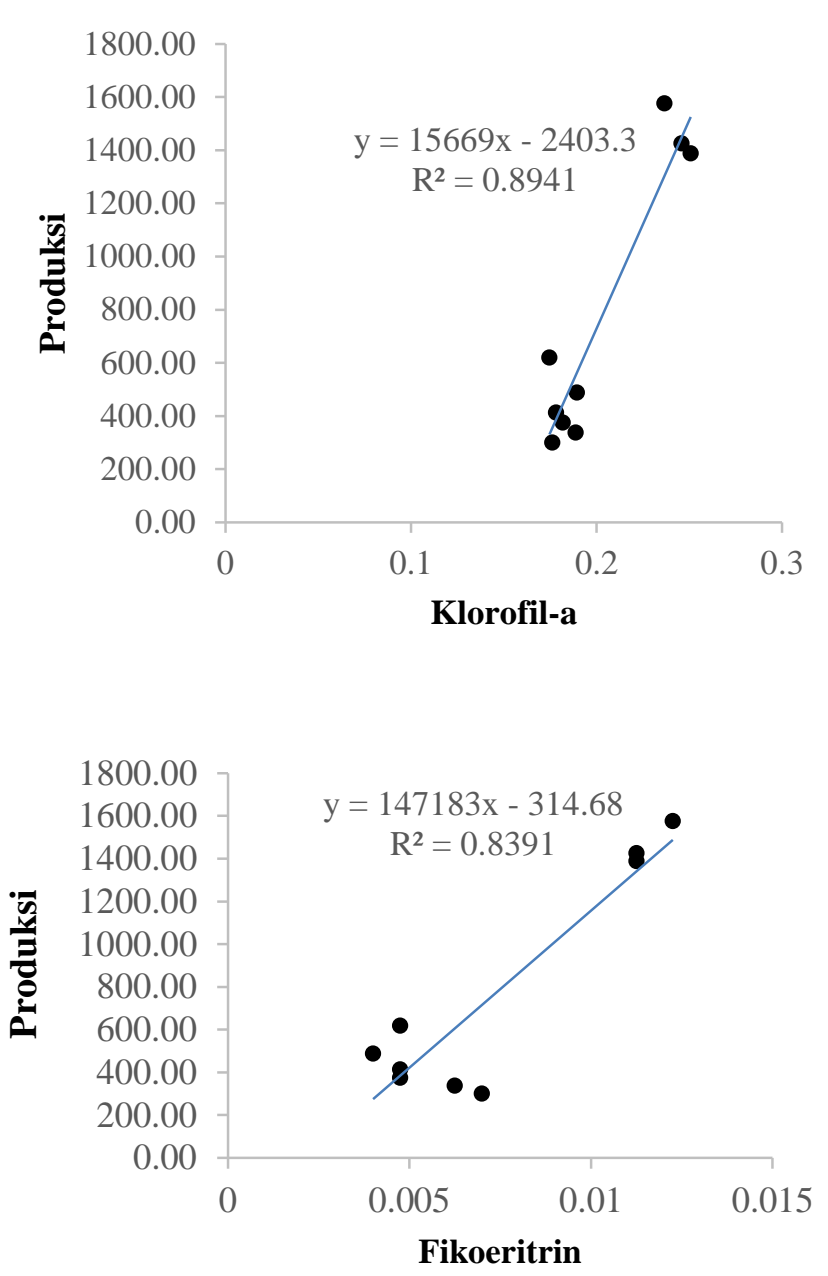

Gambar 8. Kurva hubungan klorofil-a dan fikoeritrin dengan produksi rumput laut $K$. alvarezii.

\section{KESIMPULAN}

Berdasarkan hasil penelitian dapat disimpulkan bahwa Rumput laut $K$. alvarezii varietas coklat yang dibudidaya dengan metode long line menghasilkan kuantitas terbaik.

\section{DAFTAR PUSTAKA}

Afandi A. 2010. Pengaruh jarak tanam dan bobot bibit yang berbeda terhadap pertumbuhan rumput laut varietas merah ( $K$. alvarezii) dengan metode lepas dasar [Skripsi]. Kendari (ID): Universitas Halouleo.

Amin A, Nurines OA, Subekti S. 2010. Pengaruh lama penyinaran terhadap pertumbuhan dan klorofil-a Gracilaria verrucosa pada sistem budidaya indoor. Jurnal Ilmiah Perikanan dan Kelautan. 2(1):2-7.

Atmadja WS. 2007. Apa Rumput Laut itu sebenarnya? Divisi Penelitian dan Pengembangan Rumput Laut. Kelompok Studi Rumput Laut. Semarang: UNDIP. $8 \mathrm{hlm}$.

Bahaluddin. 2006. Pengaruh jarak tanam bibit dalam pemeliharaan terhadap pertumbuhan rumput laut ( $K$. alvarezii) Doty 1988 dengan metode rakit apung di Desa Bero Kecamatan Tiworo [Skripsi]. Kendari (ID): Universitas Halouleo.

Dawes CJ. 1981. Marine Botany. John Willey and Sons. New York. 628p.

Doty MS. 1985. Eucheuma alvarezii sp. nov. (Gigartinales, Rhodophyta) from Malaysia. Abbott IA, Norris JN, editor. Taxonomy of economic seaweeds with reference to some Pacific and Caribbean species. California (US): California Sea Grant College Program. p 37-45.

Evans LV. 1988. The effects of spectral composition and irradiance level on pigment levels in seaweeds. Lobban CS, Chapman DJ, Kremer BP, editor. Experimental Phycology. New York (US). p 123-134.

Iksan KH. 2005. Kajian pertumbuhan, produksi rumput laut (Eucheuma cottonii), dan kandungan karaginan pada berbagai bobot bibit dan asal talus di perairan desa guraping oba maluku utara [Tesis]. Bogor (ID): Institut Pertanian Bogor.

Jeffrey SW, Humphrey G F. 1975. New spectrophotometric equations for determining chlorophylls $a, b, c 1$, and $c 2$ in higher plants, algae, and natural phytoplankton. Biochemie und Physiologie der Pflanzen. 167:191194.

Keputusan Menteri Negara Lingkungan Hidup Nomor 51 Tahun 2004. Tentang Baku Mutu Air Laut.

Luning K. 1990. Seaweeds, their Environment, Biogeography and Ecophysiology. New York (US). John Wiley and Sons, Inc. 527p.

Mamang N. 2008. Laju pertumbuhan bibit rumput laut Eucheuma cottonii dengan perlakuan asal thallus 
terhadap bobot bibit di perairan Lakeba, Kota Bau-Bau, Sulawesi Tenggara [Skripsi]. Bogor (ID): Institut Pertanian Bogor.

Mattjik AA, dan Sumertajaya MI. 2006. Perancangan Percobaan. Bogor: IPB Press. Jilid 1 Edisi ketiga.

Munoz J, Freile-Pelegrin Y, Robledo D. 2004. Mariculture of $K$. alvarezii (Rhodophyta, Solieriaceae) color strains in tropical waters of Yucatan, Mèxico. Aquaculture 239: 161-171.

Packer M. 2009. Algal capture of carbon dioxide: biomass generation as a tool for greenhouse gas mitigation with reference to New Zealand energy strategy and policy. Energy Policy. 37:3428-3437.

Patadjai RS. 1993. Pengaruh pupuk TSp terhadap pertumbuhan dan kualitas rumput laut Gracilaria gigas Harv [Tesis]. Bogor (ID): Institut Pertanian Bogor.

Patadjai RS. 2007. Pertumbuhan produksi dan kualitas rumput laut $K$. alvarezii Doty pada berbagai habitat budidaya yang berbeda. Makassar (ID): Universitas Hasanuddin.

Paula EJ, Pereira RTL. 2003. Factors affecting growth rates of $K$. alvarezii Doty Ex P. Silva (Rhodophyta solieriaceae) Sobtropical Waters of Sao Paulo State, Brazil. Proceedings of the XVI International Seaweed Symposium. Oxford University Press. New York. 381-388.

Rusdani MM. 2013. Analisis laju pertumbuhan dan kualitas karaginan rumput laut $K$. alvarezii yang ditanam pada kedalaman berbeda [Tesis]. Bogor (ID). Institut Pertanian Bogor.

Salisbury FB, Ross CW. 1992. Plant Physiology, 4th edition. Belmont (US): Wadsworth Publishing Co., A division of Wadsworth, Inc. 682p.

Sinaga T. 1999. Sturuktur Komunitas Rumput Laut di Perairan Rataan Terumbu Pulau Pari, Kepulauan seribu, Jakarta Utara [Skripsi]. Bogor (ID): Institut Pertanian Bogor.

[SNI 7579.2:2010] Standar Nasional Indonesia. 2010. Produksi Rumput Laut Kotoni (Eucheuma cottonii)Bagian 2: Metode long-line. Jakarta (ID): Badan Standardisasi Nasional.
Sujatmiko W, Angkasa W I. 2004. Metode Tali Panjang. Jakarta: BPPT. http://www.Iptek.net.id//ttg/18.htm. Diakses pada Tanggal 2 September 2010.

Sulistijo, Atmadja WS. 1996. Perkembangan Budidaya Rumput Laut di Indonesia. Jakarta: Puslitbang Oseanografi LIPI.

Sulma S, Manoppo A. 2008. Kesesuaian fisik perairan untuk budidaya rumput laut di perairan bali menggunakan data penginderaan jauh. Bandung: Pusat Pengembangan Pemanfaatan dan Teknologi Penginderaan Jauh LAPAN. PIT MAPIN XVII. $10 \mathrm{hlm}$.

Supit SD. 1989. Karakteristik pertumbuhan dan kandungan caragenan rumput laut (Eucheuma cottonii) yang berwarna abu-abu cokelat dan hijau yang ditanam di Goba Lambungan Pasir Pulau Pari [Skripsi]. Bogor: Institut Pertanian Bogor.

Utojo, Mansyur A, Pantjara B, Pirzan AM., Hasnawati. 2007. Kondisi lingkungan perairan Teluk Mallasora yang layak untuk lokasi pengembangan budidaya rumput laut (Eucheuma sp.). J. Ris. Akua. 2: 243-255.

Widyastuti $S, 2010$. Sifat fisik dan kimiawi karagenan yang diekstrak dari rumput laut Eucheuma cottonii dan $E$. spinosum pada umur panen yang berbeda [Skripsi]. Mataram: Universitas Mataram.

Wobeser EA, Figueroa FL, Cabello-Pasini A. 2001. Photosynthesis and growth of red and green morphotypes of $K$. alvarezii (Rhodophyta) from the Philippines. Marine Biology 138: 679686.

Zonneveld N, Huisman EA, Boon JH. 1991. Prinsip-Prinsip Budidaya Ikan. Jakarta: PT. Gramedia Utama. 